\title{
Permeability of matrices of agricultural crops to Euglossina bees (Hymenoptera, Apidae) in the Atlantic Rain Forest
}

\author{
Jaqueline Figuerêdo Rosa ${ }^{1}$, Mauro RAMALHO ${ }^{2}$, Daniela MonTEIRO ${ }^{2}$, \\ Marília Dantas e SILVA ${ }^{3}$ \\ ${ }^{1}$ Instituto Federal de Educação, Ciência e Tecnologia Baiano, Campus Guanambi, Distrito de Ceraíma, Caixa Postal 9, \\ 46430000, Guanambi, Bahia, Brazil \\ ${ }^{2}$ Laboratório de Ecologia da Polinização (ECOPOL), Instituto de Biologia, Universidade Federal da Bahia, Rua Barão de \\ Jeremoabo, s/n, Ondina, 40170115, Salvador, Bahia, Brazil \\ ${ }^{3}$ Instituto Federal de Educação, Ciência e Tecnologia Baiano, Campus Governador Mangabeira. Rua Waldemar \\ Mascarenhas, s/n, Portão, 44350000, Governador Mangabeira, Bahia, Brazil
}

Received 27 August 2014 - Revised 10 February 2015 - Accepted 20 February 2015

\begin{abstract}
We evaluate the permeability of three matrices of arboreal crops for the Euglossina bees that inhabit the Brazilian Atlantic rainforest hotspot. The comparisons of occurrences and abundances within three mosaics of forest and extensive arboreal crops (piassava palm, oil palm, and rubber tree) showed that all the matrices were permeable to most orchid bees. The piassava palm was the most permeable, where the spatial distribution of all species of Euglossina did not differ between forest fragments and matrix. The oil palm has shown some loss of permeability to Eulaema atleticana, while the rubber tree crop was not so permeable to El. atleticana and Euglossa imperialis. Euglossa iopoecila was sampled only in the forest fragments. At the present scale of forest cover in the three studied mosaics (10 to $40 \%$ ), the arboreal matrices are contributing towards the functional connectivity in the Atlantic Rain Forest at both scales: the landscape mosaic and the Brazilian Atlantic Forest corridor.
\end{abstract}

\section{functional connectivity / Euglossina / matrix habitat / agricultural crop / Atlantic Forest}

\section{INTRODUCTION}

In the face of extreme loss and fragmentation of habitats, the functional connectivity emerges as a critical variable for biodiversity conservation (Sanderson et al. 2003; Wiens 2007). The functional connectivity is the response of an organism to the structure of a landscape; thus, its evaluation requires information about the spatial configuration of the habitats and non-habitats or matrices,

Electronic supplementary material The online version of this article (doi:10.1007/s13592-015-0359-9) contains supplementary material, which is available to authorized users.

Corresponding author: J. Rosa, jaquefrosa@gmail.com

Handling Editor: Klaus Hartfelder as well as about the pattern of movements of the organisms (Tischendorf and Fahrig 2000; Crooks and Sanjayan 2007).

The effects of a matrix tend to be speciesspecific, and a more heterogeneous matrix has more probability of facilitating movements of a wider variety of organisms (Kattan and Murcia 2003). Managing the matrix may be a more effective way of managing the landscape to preserve or restore the functional connectivity; however, for this to be possible, it is necessary to understand how species interact with matrices (Fahrig 2001, 2002; Wiens 2007).

Even the forest dwellers with high mobility may be affected by the highly fragmented stage of most rainforests, as is the case of the Brazilian Atlantic Forest (e.g., Guedes et al. 2005). Euglossina bees may probably respond more 
slowly to tropical forest fragmentation due to their high mobility. The biggest Euglossine bees can fly long distances and they can cross open areas including lakes or small bays in the sea (Janzen 1971; Roubik and Hanson 2004; Wikelski et al. 2010). However, high mobility per se may not grant functional connectivity depending on the species fidelity to the forest habitats and depending on the type and extension of anthropic matrices. Some anthropic matrices can reduce connectivity while others may offer resources or even be secondary habitats for some bees (e.g., Steffan-Dewenter 2003; Jauker et al. 2009; Ramalho et al. 2013).

In this study, we evaluate the permeability of oil palm, piassava palm, and rubber tree crops to the forest dwellers Euglossina bees of Brazilian Atlantic Rain Forest (BARF). These are the most extensive perennial crops and key anthropogenic matrices in the northern portion of the Brazilian Atlantic Forest Corridor (AFC). Species-specific responses are expected to each matrix. If the degree of forest fragmentation in the north of the AFC is already affecting the mobility of some of these bee species, as we expect to happen, we should also find variable responses to the different crop matrices.

\section{MATERIAL AND METHODS}

\subsection{Study area and sample design}

The research was carried out in the Brazilian AFC, in the Camumu-Cabruca-Conduru (CCC) focal area. The AFC is a Brazilian initiative to preserve the Atlantic Rain Forest, one of the hottest "hot spot" of biodiversity in the world (Myers et al. 2000). The CCC is in the northern portion of $\mathrm{AFC}$ and comprises the minicorridors Restinga (Sandbanks) and Papuã-Pratigi (Batista 2008; Online Resource 1) at Bahia State (Brazil).

Three landscape mosaics were chosen in the $\mathrm{CCC}$, with native forest remnants and the three main regional crop matrices, in terms of extension of cultivated land area: (1) mosaic with the oil palm matrix (Elaeis guineensis Jacq.); (2) mosaic with the piassava palm matrix (Attalea funifera Mart.); (3) mosaic with the rubber tree matrix (Hevea brasiliensis Muell. Arg.).

The oil palm and piassava palm reach between 15 and $20 \mathrm{~m}$ high. They form perennial crops which demand little mechanization and reduced employment of agricultural pesticides (Guimarães and Silva 2012; Brazilio et al. 2012). The oil palm tree is exotic and, in general, it is planted with $7.8 \mathrm{~m}$ spacing between-lines and $9 \mathrm{~m}$ betweenplants in lines, reaching density of 143 plants/ha (Cordeiro et al. 2009). The piassava palm is endemic to Bahia's coastline. In the studied mosaic, the piassava palms are managed in agroforestry systems, where individuals in different stages of vegetative growth are randomly distributed (around 400 plants/ha), growing with other native tree species from the Atlantic forest (Guimarães and Silva 2012). The Atlantic forest covers around 10-20\% of the area of both the piassava and oil palm mosaics.

The selected forest-rubber tree mosaic encompasses the neighboring protected forest areas of Michelin Ecological Reserve (MER) with 3,096 ha of protected tropical rainforest at altitudes from 160 to 327 masl. The forest covers around $43 \%$ of the area of this mosaic and is concentrated in two northern large blocks (625 and 550 ha, the last one connected to neighboring forests of CCC, covering more than 4,000 ha of continuous forests), in addition to narrow riverine forests (10$13 \mathrm{~m}$ width) and many small forest fragments $(<15$ ha) imbedded in rubber tree matrix which occupies about $30 \%$ of the mosaic area (Ramalho et al. 2013). The rubber trees are often planted with 7 to $8 \mathrm{~m}$ spacing between-lines and $2.5-3 \mathrm{~m}$ in the line, with density of $476-500$ trees/ ha, and the adult trees can reach $40-50 \mathrm{~m}$ in height (Duarte 2007).

\subsection{Bee sampling}

In each of the three crop-forest mosaics, two odor traps were installed in three replicates of the following treatments: (1) the nuclear area of forest fragments (identified as $0 \mathrm{~m}$ treatment) and crop matrix in (2) $500 \mathrm{~m}$, (3) $1,000 \mathrm{~m}$, and (4) $2,000 \mathrm{~m}$ away from the edge of the forest fragment.

The two odor traps of each replicate were $100 \mathrm{~m}$ distant from each other and installed 
$1.5 \mathrm{~m}$ above ground. The odor trap and the attractive aromatic compound (eucalyptol or 1.8-cineol) were standardized following Ramalho et al. (2013). The field samplings were simultaneous inside each mosaic, but not among mosaics (Online Resource 2 ). The sampling were carried out including the most active periods of orchid bees in the region (November to March; Ramalho et al. 2013), during two consecutive days and $48 \mathrm{~h}$ per period, and totalizing $144 \mathrm{~h}$ per mosaic (in three Sampling Period, see Online Resource 2).

The sampled bee males are deposited in Pollination Ecology Lab (ECOPOL) of the Federal University of Bahia (UFBA). The species were determined by comparison with the reference material (identified by Dr. André Nemésio-Federal University of Uberlândia-MG-Brazil) and using identification keys of Nemésio (2009). Nomenclature of Nemésio (2009) was adopted. To ease communication, we utilized the following abbreviations for the genera: Eg. = Euglossa, El. = Eulaema, and Ex. = Exaerete.

\subsection{Statistical analysis}

First, it was made an exploratory analysis of the distance effect, grouping data on the three mosaics. Second, individual analyses were carried out for each type of mosaics by considering the following factors: distance from forest fragment and time (each sampling period was a treatment/factor level). Multivariate (species composition) and univariate (total abundance) variance analyses (MANOVA and ANOVA) were performed, the post hoc tests were made using the Tukey's Honestly Significant Differences test, and the Pillai's trace multivariate test method was also used. All orchid bee species in the analyses of total abundance and only the species with more than 50 sampled individuals in the analyses per species were taken into account.

The data normality and homoscedasticity were evaluated, respectively, with the KolmogorovSmirnov test and with the Levene's Variances Equality test. All tests were made in the statistics program SPSS 13.0 for Windows and the significance level adopted was 0.05 . The dependent variables that did not satisfy the normality premise of the analysis of variance were transformed using natural logarithm plus one $(\ln [X+1]$, where $X$ is the value to be transformed).

\section{RESULTS}

A total of 21 orchid bee species were sampled in the three crop-forest mosaics of the AFC, from which the most abundant ones were, in descending order: Eulaema nigrita Lepeletier, 1841 (1399), Euglossa ignita Smith, 1874 (512), Euglossa carolina Nemésio, 2009 (506), Eulaema atleticana Nemésio, 2009 (486), Euglossa imperialis Cockerell, 1922 (88), and Euglossa securigera Dressler, 1982 (54) (Online Resource 3).

The species composition and the most abundant species differed among the types of mosaics, except for the Eg. carolina (Table I). In contrast, the less abundant species showed no differences between mosaics, except for the Euglossa iopoecila, which was sampled only in the mosaic of forest with rubber tree matrix (Table I, Online Resource 2).

Only El. atleticana, Eg. imperialis, and Eg. iopoecila showed differences in the number of bees captured between the forest and crop matrices (Table I; Online Resource 4). The Eg. iopoecila, in particular, was collected only in the interior of forest fragments. However, the three species presented no variation in abundance associated to distances inside the three matrices (Table II).

The apparent response of Eg. imperialis to the interaction of factors (mosaic type and distance) is related with its strong difference between the forest fragment and the rubbermatrix (Table III). The Eg. iopoecila significant interaction resulted of its absence in two of three mosaics (forest mosaics with oil palm and piassava palm).

Among the most abundant species, El. atleticana and Eg. imperialis showed variation between forest and rubber tree matrix that also explain the significant spatial variation in the total abundance of Euglossina in this mosaic (Table III; Figure 1). Only El. atleticana decreased in abundance in the oil palm matrix in relation to the forest (Table III). In the piassava palm mosaic (MPM), the abundances 
Table I. Effect of distance from the forest fragment on the permeability of arboreal matrices to Euglossina. $p=$ probability.

Dependent variable Mosaic type $(p) \quad$ Distance from Forest $(p) \quad$ Mosaic type $\times$ distance from forest $(p)$

\begin{tabular}{llll}
\hline Species composition (Pillai's trace) & 0.045 & 0.267 & 0.534 \\
Total abundance & 0.077 & 0.224 & 0.625 \\
Eulaema nigrita & 0.020 & 0.898 & 0.593 \\
Euglossa ignita & 0.025 & 0.127 & 0.827 \\
Euglossa carolina & 0.094 & 0.323 & 0.422 \\
Eulaema atleticana & 0.001 & 0.002 & 0.312 \\
Euglossa imperialis & 0.000 & 0.001 & 0.001 \\
Euglossa securigera & 0.005 & 0.888 & 0.681 \\
Euglossa clausi & 0.000 & 0.263 & 0.161 \\
Euglossa liopoda & 0.955 & 0.950 & 0.333 \\
Exaerete frontalis & 0.118 & 0.910 & 0.543 \\
Euglossa melanotricha & 0.067 & 0.401 & 0.078 \\
Euglossa hemichlora & 0.136 & 0.293 & 0.445 \\
Euglossa iopoecila & 0.033 & 0.020 & 0.007 \\
Euglossa despecta & 0.613 & 0.364 & 0.942 \\
Euglossa crassipunctata & 0.282 & 0.071 & 0.281 \\
Euglossa carinilabris & 0.585 & 0.562 & 0.365 \\
Eulaema niveofasciata & 0.383 & 0.801 & 0.448 \\
Euglossa truncata & 0.613 & 0.141 & 0.802 \\
Exaerete smaragdina & 0.157 & 0.581 & 0.677 \\
Euglossa aratingae & 0.383 & 0.410 & 0.448 \\
Euglossa leucotricha & 0.383 & 0.410 & 0.448 \\
Euglossa nanomelanotricha & 0.383 & 0.410 & 0.448 \\
\hline
\end{tabular}

of no species varied between the forest and the matrix and, therefore, there was no influence of the distance into the matrix in relation to the forest (Table III; Figure 2).

The time factor affected the species composition and the abundance of about $50 \%$ of the species in the three mosaic types, and total abundance of orchid bees in the forestrubber mosaic (Table III), that probably reflect a marked seasonal variation of flying activity of orchid bees in the region. Only Eg. imperialis responded to interaction of factors time and distance at rubber mosaic (Table III), but probably this could be due to insufficient number of individuals sampled in some period of the year (Table IV).
Therefore, the spatial distribution of Euglossina in each mosaic type was weakly affected by the period of the year (Table III).

In the few cases of significant differences between forest and matrix (Table III), there were no influence of the distances in the matrix on observed variation in abundance (Table V; Figures 2 and 3). When there is some influence of the matrix on the orchid bees, this is not related to its extension in the landscape.

\section{DISCUSSION}

In general, the palms and rubber tree matrices were permeable to most of the Euglossina 
Table II. Paired comparisons (post hoc test) of the effect of "distance from the forest fragment" on the permeability of the arboreal matrices. Treatments: $\mathrm{A}=0 \mathrm{~m}$ (inside the forest fragment), $\mathrm{B}=500 \mathrm{~m}, \mathrm{C}=$ $1,000 \mathrm{~m}, \mathrm{D}=2,000 \mathrm{~m}$ inside de matrix. $p=$ probability.

\begin{tabular}{llc}
\hline Dependent variable (Euglossine species) & Paired comparisons & $p$ value \\
\hline Eulaema atleticana & $\mathrm{A} \times \mathrm{B}$ & 0.042 \\
& $\mathrm{~A} \times \mathrm{C}$ & 0.002 \\
& $\mathrm{~A} \times \mathrm{D}$ & 0.018 \\
& $\mathrm{~B} \times \mathrm{C}$ & 0.550 \\
& $\mathrm{~B} \times \mathrm{D}$ & 0.980 \\
Euglossa imperialis & $\mathrm{C} \times \mathrm{D}$ & 0.779 \\
& $\mathrm{~A} \times \mathrm{B}$ & 0.004 \\
& $\mathrm{~A} \times \mathrm{C}$ & 0.002 \\
& $\mathrm{~A} \times \mathrm{D}$ & 0.006 \\
& $\mathrm{~B} \times \mathrm{C}$ & 0.994 \\
& $\mathrm{~B} \times \mathrm{D}$ & 0.998 \\
& $\mathrm{C} \times \mathrm{D}$ & 0.972 \\
& $\mathrm{~A} \times \mathrm{B}$ & 0.045 \\
& $\mathrm{~A} \times \mathrm{C}$ & 0.045 \\
& $\mathrm{~A} \times \mathrm{D}$ & 0.045 \\
& $\mathrm{~B} \times \mathrm{C}$ & 1.000 \\
& $\mathrm{~B} \times \mathrm{D}$ & 1.000 \\
& $\mathrm{C} \times \mathrm{D}$ & 1.000 \\
\hline
\end{tabular}

species. The piassava palm crop was more heterogeneous and more permeable than the other two matrices, as expected. Some studies have pointed out that the heterogeneity and quality of matrices affect the richness and abundance of bees and wasps in general (both from the Hymenoptera group), with varied influences on different species (e.g., Steffan-Dewenter and
Tscharntke 1999; Steffan-Dewenter 2003; Jauker et al. 2009).

The piassava is harvested in areas of native forest submitted to extensive selective cut and clearing of large native trees. This agroforestry system still preserves native plant and mainly understory species (Guimarães and Silva 2012) that offer key flower resources

Table III. Effects of distance (from the forest fragment), time, and interaction of the both factors on the permeability of arboreal matrices to Euglossine bees. MRM = mosaic of forest fragments and rubber tree matrix; MPM = mosaic of forest fragments and piassava palm matrix; $\mathrm{MOM}=$ mosaic of forest fragments and oil palm matrix. $p=$ probability.

\begin{tabular}{|c|c|c|c|c|c|c|c|c|c|}
\hline \multirow[t]{2}{*}{ Dependent variable } & \multicolumn{3}{|c|}{ Distance from forest $(p)$} & \multicolumn{3}{|c|}{ Time $(p)$} & \multicolumn{3}{|c|}{ Time $\times$ distance from forest $(p)$} \\
\hline & MRM & MPM & MOM & MRM & MPM & MOM & MRM & MPM & MOM \\
\hline Species composition & 0.128 & 0.364 & 0.907 & 0.000 & 0.011 & 0.000 & 0.907 & 0.033 & 0.961 \\
\hline Total abundance & 0.053 & 0.991 & 0.510 & 0.002 & 0.960 & 0.085 & 0.235 & 0.514 & 0.849 \\
\hline Eulaema atleticana & 0.049 & 0.221 & 0.043 & 0.001 & 0.056 & 0.294 & 0.257 & 0.947 & 0.764 \\
\hline Eulaema nigrita & 0.570 & 0.547 & 0.607 & 0.000 & 0.853 & 0.000 & 0.470 & 0.669 & 0.624 \\
\hline Euglossa carolina & 0.264 & 0.245 & 0.929 & 0.278 & 0.016 & 0.191 & 0.977 & 0.204 & 0.869 \\
\hline Euglossa ignita & 0.345 & 0.452 & 0.265 & 0.854 & 0.018 & 0.018 & 0.795 & 0.098 & 0.725 \\
\hline Euglossa imperialis & 0.008 & 0.512 & 0.548 & 0.082 & 0.243 & 0.441 & 0.046 & 0.135 & 0.805 \\
\hline Euglossa securigera & 0.819 & 0.160 & 0.851 & 0.314 & 0.119 & 0.010 & 0.531 & 0.064 & 0.933 \\
\hline
\end{tabular}



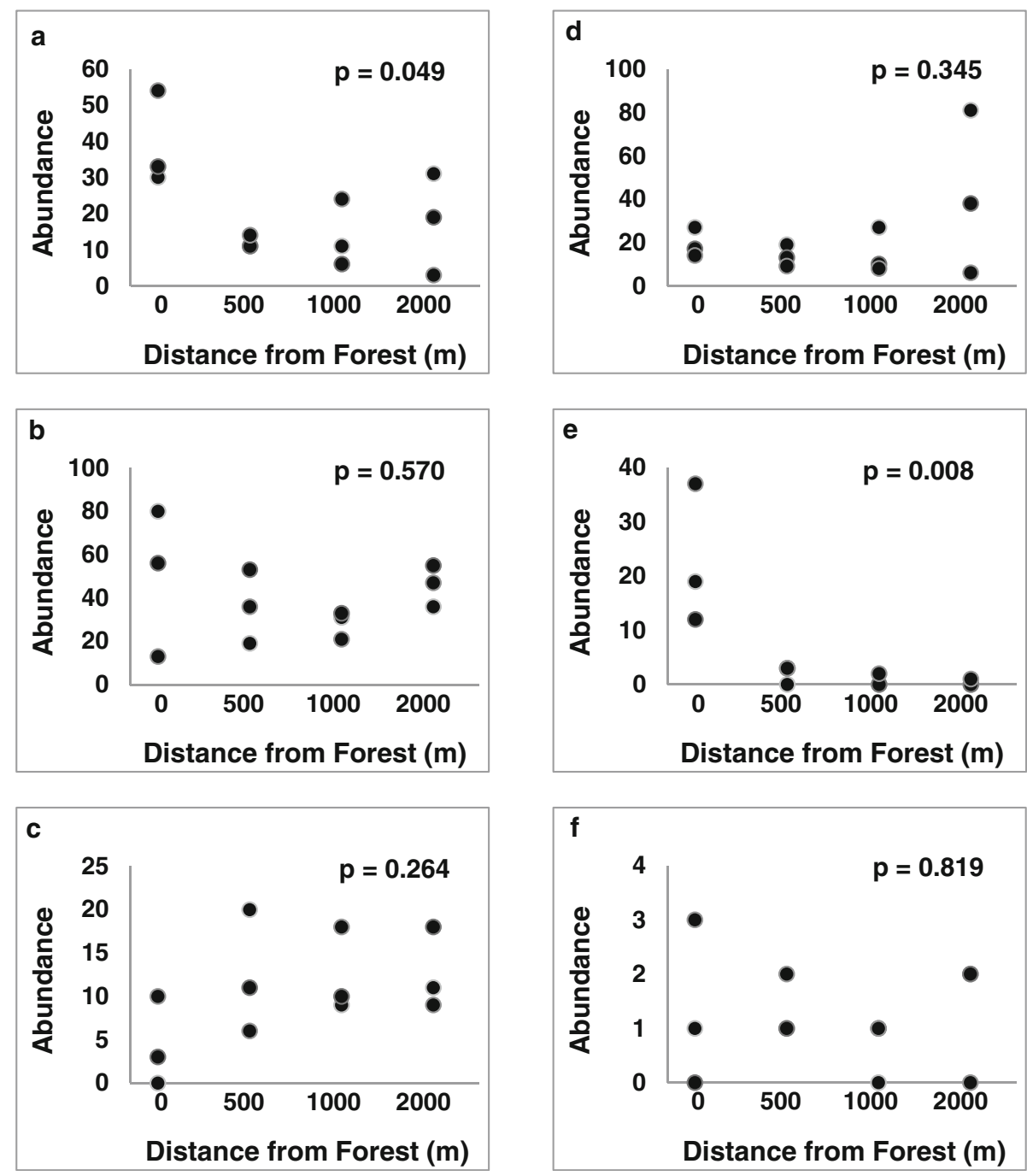

Figure 1. Spatial distribution of abundance (number of individuals) of the most abundant species of Euglossine bees in the forest-rubber tree mosaics in the Brazilian Atlantic Forest Corridor. a El. atleticana; b El. nigrita; c Eg. carolina; d Eg. ignita; e Eg. imperialis; f Eg. securigera.

to bees' preservation (Roulston and Goodell 2011), moderate shading conditions, and therefore, better general conditions of occupation by orchid bees.

Of the 21 sampled Euglossina species, only three have reduced abundances in the matrices: El. atleticana in the oil palm tree matrix; El. atleticana, Eg. imperialis, and Eg. iopoecila in the rubber tree matrix. This last orchid bee was sampled exclusively in the more extensive forest block of the region, indicating sensitivity to forest fragmentation and disturbance. The reduction of permeability to the other two Euglossina species did not lead to the loss of functional connectivity in the mosaic scale, at least to the level of current forest fragmentation.

El. atleticana and Eg. imperialis were the only ones who responded to the forest fragment size and presented lower capture rate in 

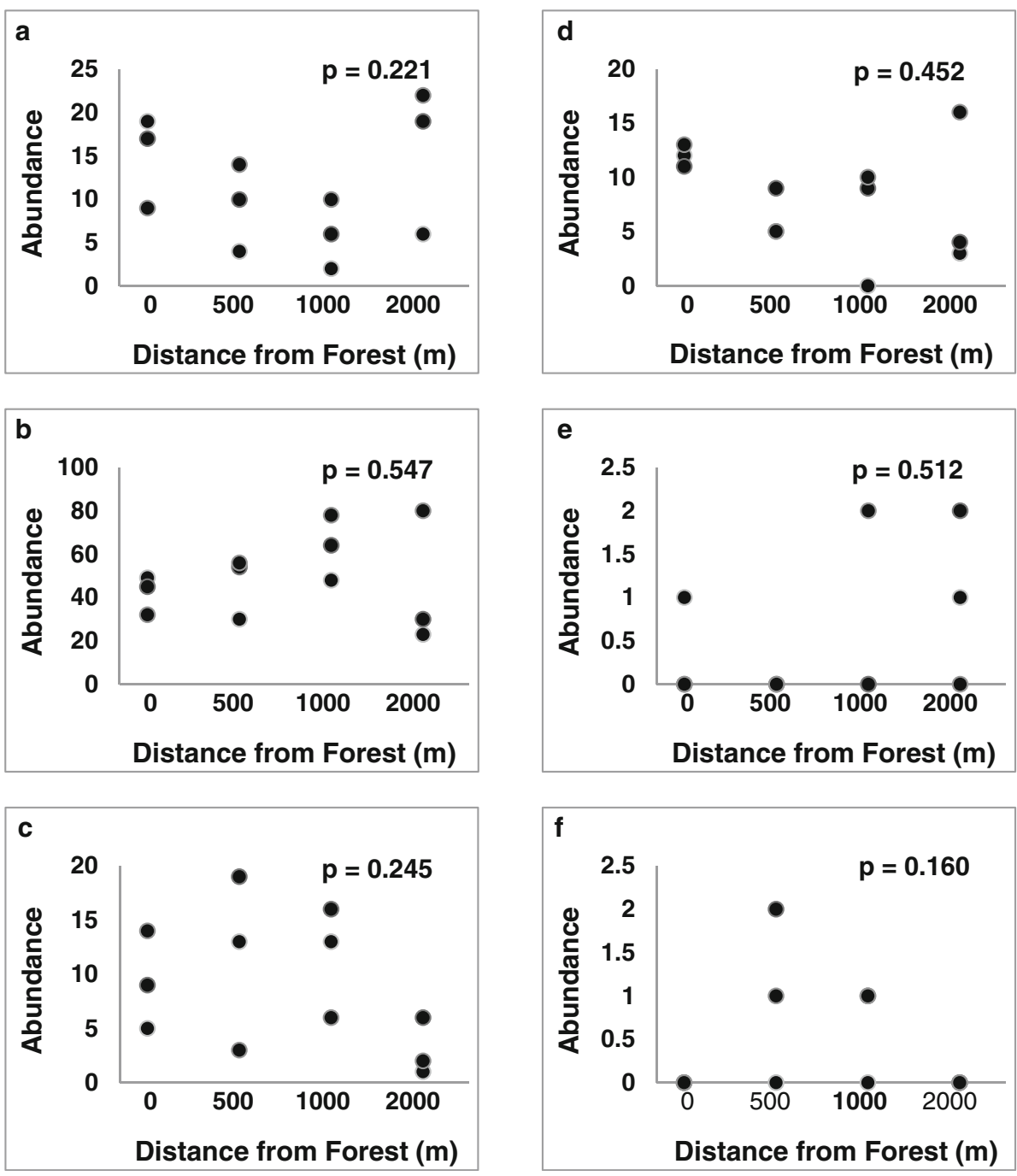

Figure 2. Spatial distribution of abundance (number of individuals) of the most abundant species of Euglossine bees in the forest-piassava palm mosaics in the Brazilian Atlantic Forest Corridor. a El. atleticana; b El. nigrita; c Eg. carolina; d Eg. ignita; e Eg. imperialis; f Eg. securigera .

rubber tree crops and other anthropic habitats compared to the nearby forest areas (MiletPinheiro and Schlindwein 2005; Aguiar 2011; Ramalho et al. 2013; this study). Therefore, evidences indicate that these two species are presenting lower ability of exploiting the anthropogenic habitats in expansion with regional deforestation (this study; Aguiar 2011; Ramalho et al. 2013). Although they are able to explore non-arboreal environments, they seem to be sensitive to changes of forest cover in the landscape. Therefore, El. atleticana and Eg. imperialis are good candidates to function as bioindicators.

On the other extreme, the species El. nigrita and Eg. carolina were weakly affected by fragmentation metrics, such as the forest fragment size (e.g., Aguiar 2011; Ramalho et al. 2013), and they forage in 
Table IV. Paired comparisons (post hoc test) of the effect of factor distance from the forest fragment on the permeability of Eg. imperialis in the forest-rubber tree mosaic. Treatments: $\mathrm{A}=0 \mathrm{~m}$ (forest fragment), $\mathrm{B}=500 \mathrm{~m}, \mathrm{C}=$ $1,000 \mathrm{~m}, \mathrm{D}=2,000 \mathrm{~m}$.

\begin{tabular}{|c|c|c|c|c|}
\hline \multirow[t]{2}{*}{ Sampling period } & \multirow[t]{2}{*}{ Absolute abundance } & \multirow[t]{2}{*}{$p$ value } & \multicolumn{2}{|l|}{ post hoc test } \\
\hline & & & Combinations in the factor & $p$ \\
\hline \multirow[t]{6}{*}{03 and 04/08/2009 } & \multirow[t]{6}{*}{14} & \multirow[t]{6}{*}{0.027} & $\mathrm{~A} \times \mathrm{B}$ & 0.038 \\
\hline & & & $\mathrm{A} \times \mathrm{C}$ & 0.085 \\
\hline & & & $\mathrm{A} \times \mathrm{D}$ & 0.038 \\
\hline & & & $\mathrm{B} \times \mathrm{C}$ & 0.940 \\
\hline & & & $\mathrm{B} \times \mathrm{D}$ & 1.000 \\
\hline & & & $\mathrm{C} \times \mathrm{D}$ & 0.940 \\
\hline \multirow[t]{6}{*}{04 and $05 / 02 / 2010$} & \multirow[t]{6}{*}{52} & \multirow[t]{6}{*}{0.053} & $\mathrm{~A} \times \mathrm{B}$ & 0.101 \\
\hline & & & $\mathrm{A} \times \mathrm{C}$ & 0.078 \\
\hline & & & $\mathrm{A} \times \mathrm{D}$ & 0.085 \\
\hline & & & $\mathrm{B} \times \mathrm{C}$ & 0.998 \\
\hline & & & $\mathrm{B} \times \mathrm{D}$ & 0.999 \\
\hline & & & $\mathrm{C} \times \mathrm{D}$ & 1.000 \\
\hline \multirow[t]{6}{*}{12 and 13/11/2010 } & \multirow[t]{6}{*}{9} & \multirow[t]{6}{*}{0.219} & $\mathrm{~A} \times \mathrm{B}$ & 0.754 \\
\hline & & & $\mathrm{A} \times \mathrm{C}$ & 0.264 \\
\hline & & & $\mathrm{A} \times \mathrm{D}$ & 0.264 \\
\hline & & & $\mathrm{B} \times \mathrm{C}$ & 0.754 \\
\hline & & & $\mathrm{B} \times \mathrm{D}$ & 0.754 \\
\hline & & & $\mathrm{C} \times \mathrm{D}$ & 1.000 \\
\hline
\end{tabular}

different matrices, moving through extensive areas of open vegetation (e.g., Tonhasca et al. 2003; Aguiar 2011; Ramalho et al. 2013). Because of these characteristics, they could mitigate the rupture of important ecosystem functions in extremely deforested landscapes of AFC, in particular the longdistance pollination.

There is no consensus regarding the intensities and main effects of the forest fragmentation on the Euglossine bees (see brief review in Ramalho et al. 2013). However, most $(70 \%)$ of the studies have reported effects of some fragmentation metrics (for example, fragment size or core area, areaedge ratio, habitat quality) on the diversity and/or the abundance of those bees (e.g., Powell and Powell 1987; Raw 1989; Peruquetti et al. 1999; Otero and Sandino 2003; Sofia and Suzuki 2004; Darrault et al.
2006; Brosi 2009; Ramalho et al. 2009, 2013; Nemésio and Silveira 2010; Aguiar and Gaglianone 2012). On the contrary, few cases did not report any effects of the forest fragment size or quality on orchid bees (Becker et al. 1991; Tonhasca et al. 2002; Rasmussen 2009).

Therefore, the Euglossine bees seem to be affected by the forest fragmentation to the habitat patch level, and often their abundance and/or richness respond to the area, shape, and/or quality of fragment. This kind of relationship is highly expected and had already been observed in various taxonomic groups since the theory of islands biogeography by MacArthur and Wilson's (1967) became popular in the studies on habitat fragmentation (Kattan and Murcia 2003).

Some studies point out the high correlation between the body size and foraging distance 
Table V. Paired comparisons (post hoc test) of the effect of "distance from the forest fragment" on the permeability of matrices to the Euglossina, per type of mosaic. MRM, MPM, and MOM as in Table III. Treatments: A=0 m (forest fragment), $\mathrm{B}=500 \mathrm{~m}, \mathrm{C}=1,000 \mathrm{~m}, \mathrm{D}=2,000 \mathrm{~m}$.

\begin{tabular}{llll}
\hline Dependent variable (Euglossine species) & Paired comparisons & MRM $(p)$ & MOM $(p)$ \\
\hline Total abundance & $\mathrm{A} \times \mathrm{B}$ & 0.116 & - \\
& $\mathrm{A} \times \mathrm{C}$ & 0.072 & - \\
& $\mathrm{A} \times \mathrm{D}$ & 0.834 & - \\
& $\mathrm{B} \times \mathrm{C}$ & 0.986 & - \\
Eulaema atleticana & $\mathrm{B} \times \mathrm{D}$ & 0.354 & - \\
& $\mathrm{C} \times \mathrm{D}$ & 0.232 & - \\
& $\mathrm{A} \times \mathrm{B}$ & 0.058 & 0.059 \\
& $\mathrm{~A} \times \mathrm{C}$ & 0.077 & 0.054 \\
& $\mathrm{~A} \times \mathrm{D}$ & 0.146 & 0.577 \\
& $\mathrm{~B} \times \mathrm{C}$ & 0.997 & 0.543 \\
Euglossa imperialis & $\mathrm{B} \times \mathrm{D}$ & 0.913 & 1.000 \\
& $\mathrm{C} \times \mathrm{D}$ & 0.966 & - \\
& $\mathrm{A} \times \mathrm{B}$ & 0.020 & - \\
& $\mathrm{A} \times \mathrm{C}$ & 0.014 & - \\
& $\mathrm{A} \times \mathrm{D}$ & 0.013 & - \\
& $\mathrm{B} \times \mathrm{C}$ & 0.994 & - \\
\hline
\end{tabular}

in different groups of bees (e.g., Van Nieuwstadt and Ruano Iraheta 1996; Gathmann and Tscharntke 2002; Greenleaf et al. 2007). Most Euglossines are large bees and various species stand out for its very large body size, for example, El. atleticana and $E l$. nigrita have average body size of 26.7 and $19 \mathrm{~mm}$, respectively (Nemésio 2009). Thereby, the size of some orchid bees offers an explanatory component to long forage distances or willingness of crossing or exploring non-forested environments (e.g., Janzen 1971; Powell and Powell 1987; Roubik and Hanson 2004; Wikelski et al. 2010).

However, in this study, there is no evidence that the size has relevant influence or predictive power on the responses of orchid bees, e.g., the observed similar responses to matrices of two species with very different body sizes: El. atletican a and Eg. imperialis (26.7 and $15 \mathrm{~mm}$, respectively; Nemésio 2009).
With regard to mobility of orchid bees, the relevant issue should be the quality of the matrices in terms of floral resources (e.g., Roulston and Goodell 2011), but not necessarily in terms of the physiognomy (e.g., arboreal and non-arboreal matrices; see also Ramalho et al. 2013). If the density of planted trees/ha would have relevant influence on the quality of the agricultural matrices to the orchid bees, the rubber matrix (500 trees/ha) should provide greater permeability than the oil palm tree (140 palm trees/ ha), and this was not confirmed. The effects of the quality and heterogeneity of the matrices on mobility were reported on various groups of insects (e.g., Ricketts 2001; Winfree et al. 2011).

Regarding most of the Euglossina bee species, the arboreal matrices of piassava palm, oil palm, and rubber trees must contribute to maintain a moderate connectivity level and gene flow (Rosa et al., unpublished data), 

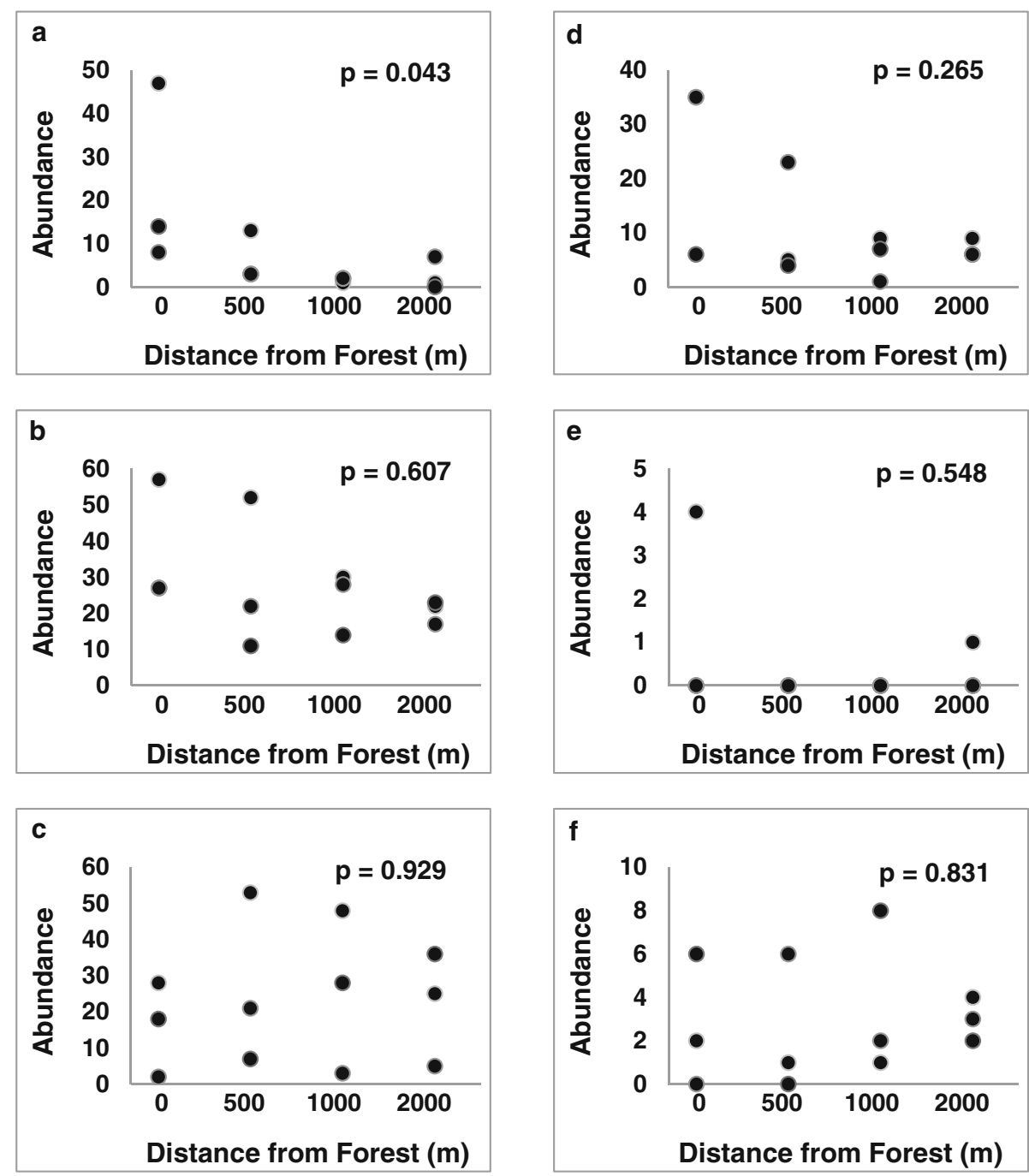

Figure 3. Spatial distribution of abundance (number of individuals) of the most abundant species of Euglossine in the forest-oil palm mosaics in the Brazilian Atlantic Forest Corridor. a El. atleticana; b El. nigrita; c Eg. carolina; d Eg. ignita; e Eg. imperialis; $\mathbf{f}$ Eg. securigera .

considering the current level of forest cover and fragmentation in the northern AFC. However, the species-specific responses are becoming evident, considering the differential sensibility of El. atleticana and $E g$. imperialis to the current fragmentation level.

The northern portion of the Atlantic Forest Corridor is composed by a high proportion of small forest fragments $(<10 \mathrm{ha})$ and riverine forests, and rare large fragments (>100 ha) (Fundação SOS Mata Atlântica and INPE 2013;
Ramalho et al. 2013). The small fragments and the riverine forests are still being occupied by Euglossine bees (Ramalho et al. 2013) and might be serving, respectively, as stepping stones or biological corridors in the current stage of forest fragmentation. However, with increasing risk of disappearance of such connecting elements at the landscape scale, the regional arboreal matrices with depleted understory vegetation must loose connectivity to most sensitive species of orchid bees living in forest. 


\section{ACKNOWLEDGMENTS}

The authors thank the following: to Dr. André Nemésio from the Federal University of Uberlândia for identification of the Euglossine specimens that served as a reference collection; to the 'Óleos de Palma S/A-Agroindustrial' (OPALMA) and Mr Valso for making their properties accessible to sampling and especially to Michelin for the logistic support; to $\mathrm{CNPq}$ (process 474313/2011-5) for the financial support, and Fapesb for PhD scholarship to JFR; and to the colleagues from the Pollination Ecology Lab (ECOPOLIBUFBA), for helping in the fieldwork.

Perméabilité des matrices de cultures arborées aux abeilles Euglossines (Hymenoptera, Apidae) dans la forêt atlantique pluvieuse

relation fonctionnelle / abeilles à orchidée / culture extensive / mosaïque forestière / Brésil

Durchlässigkeit der Matrix von landwirtschaftlich genutzten Pflanzen für Euglossina Bienen (Hymenoptera, Apidae) im Atlantischen Regenwald

funktionelle Konnektivität / Euglossina / Matrixhabitat / landwirtschaftliche Nutzpflanze / Atlantischer Wald

\section{REFERENCES}

Aguiar, W. M. (2011) Estrutura das comunidades de abelhas Euglossina (Hymenoptera; Apidae) e variabilidade genética de Eulaema cingulata Fab. em fragmentos florestais no estado do Rio de Janeiro. Dissertação, Universidade Estadual do Norte Fluminense [online] http://uenf.br/pos-graduacao/ ecologia-recursosnaturais/files/2013/11/WillianAguiar.pdf (accessed on 10 February 2015)

Aguiar, W.M., Gaglianone, M.C. (2012) Euglossine bee communities in small forest fragments of Atlantic Forest, Rio de Janeiro state, southeastern Brazil (Hymenoptera, Apidae). Rev. Bras. Entomol. 56 (2), 210-219

Batista, M.A. (2008) Áreas focais e minicorredores no Corredor Central da Mata Atlântica na Bahia. In: Lima, R.X. (ed.) Experiências em Implementação de Corredores Ecológicos, pp. 19-23. MMA, Brasília

Becker, P., Moure, J.S., Peralta, F.J.A. (1991) More about euglossine bees in Amazonian forest fragments. Biotropica 24 (4b), 586-591

Brazilio, M., Bistachio, N.J., Perina, V.C.S., Nascimento, D.D. (2012) O Dendezeiro (Elaeis guineensis Jacq.) Revisão. Bioenergia Rev. 2(1), 27-45
Brosi, B.J. (2009) The effects of forest fragmentation on euglossine bee communities (Hymenoptera: Apidae: Euglossina). Biol. Conserv. 142, 414-423

Cordeiro, A.C.C., Alves, A.B..., Maciel, F.C.S. (2009) Informações Técnicas para a Implantação de Lavoura de Dendê em Roraima. Embrapa Roraima, Boa Vista

Crooks, K.R., Sanjayan, M. (2007) Connectivity conservation: maintaining connections for nature. In: Crooks, K.R., Sanjayan, M. (eds.) Connectivity conservation, pp. 2-19. Cambridge University Press, Cambridge

Darrault, R.O., Medeiros, P.C.R., Locatelli, E., Lopes, A.V., Machado, I.C., Schlindwein, C. (2006) Abelhas Euglossine. In: Pôrto, K.C., Almeida-Cortêz, J.S., Tabarelli, M. (eds.) Diversidade Biológica e Conservação da Floresta Atlântica ao Norte do Rio São Francisco, pp. 238-253. MMA, Brasília

Duarte, J.D. (2007) Seringueira: Da Implantação ao Beneficiamento Primário. Ministério da Agricultura, Pecuária e Abastecimento, Valença

Fahrig, L. (2001) How much habitat is enough? Biol. Conserv. 100, 65-74

Fahrig, L. (2002) Effects of habitat fragmentation on the extinction threshold: a synthesis. Ecol. Appl. 12 (2), 346-353

Fundação SOS Mata Atlântica, INPE-Instituto Nacional de Pesquisas Espaciais (2013) Relatório técnico do atlas dos remanescentes florestais da Mata Atlântica: período 2011-2012. Fundação SOS Mata Atlântica, Instituto Nacional de Pesquisas Espaciais, São Paulo

Gathmann, A., Tscharntke, T. (2002) Foraging ranges of solitary bees. J. Anim. Ecol. 71, 757-764

Greenleaf, S.S., William, N.M., Winfree, R., Kremen, C. (2007) Bee foraging range and their relationship to body size. Oecologia 153, 589-596

Guedes, M.L.S., Batista, M.A., Ramalho, M., Freitas, H.M.B., Silva, E.M. (2005) Breve Incursão sobre a Biodiversidade da Mata Atlântica. In: Franke, C.R., Rocha, P.L.B., Klein, W., Gomes, S.L. (eds.) Mata Atlântica e Biodiversidade, pp. 39-92. Edufba, Salvador

Guimarães, C.A.L., Silva, L.A.M. (2012) Piaçava da Bahia (Attalea funifera Martius): Do Extrativismo à Cultura Agrícola. Editus, Ilhéus

Janzen, D.H. (1971) Euglossine bees as long distance pollinators of tropical plants. Science 171 , 203-205

Jauker, F., Diekötter, T., Schwarzbach, F., Wolters, V. (2009) Pollinator dispersal in an agricultural matrix: opposing responses of wild bees and hoverflies to landscape structure and distance from main habitat. Landsc. Ecol. 24, 547-555

Kattan, G.H., Murcia, C. (2003) A review and synthesis of conceptual frameworks for the study of forest fragmentation. In: Bradshaw, G.A., Marquet, P.A. (eds.) How Landscapes Change. Ecological Studies, pp. 183-200. Springer-Verlag, Berlin

MacArthur, R.H., Wilson, E.O. (1967) The Theory of Island Biogeography. Monographs in Population Biology. Princeton University Press, Princeton 
Milet-Pinheiro, P., Schlindwein, C. (2005) Do Euglossine males (Apidae, euglossine) leave tropical rain forest to collect fragrances in sugar cane monocultures? Rev. Bras. Zool. 22 (4), 853-858

Myers, N., Mittermeier, R.A., Mittermeier, C.G., Fonseca, G.A.B..., Kent, J. (2000) Biodiversity hotspots for conservation priorities. Nature 403, 853-858

Nemésio, A. (2009) Orchid bees (Hymenoptera: Apidae) of the Brazilian Atlantic Forest. Zootaxa 2041 , 1-242

Nemésio, A., Silveira, F. (2010) A. Forest Fragments with larger core areas better sustain diverse Orchid Bee faunas (Hymenoptera: Apidae: Euglossina). Neotrop. Entomol. 39(4), 555-561

Otero, J.T., Sandino, J.C. (2003) Capture rates of male Euglossine bees across human intervention gradient, Chocó region, Colombia. Biotropica 35 (4), 520-529

Peruquetti, R.C., Campos, L.A.O., Coelho, C.D.P., Abrantes, C.V.M., Lisboa, L.C.O. (1999) Abelhas Euglossine (Apidae) de áreas de Mata Atlântica: abundância, riqueza e aspectos biológicos. Rev. Bras. Zool. 16(2), 101-118

Powell, A.H., Powell, G.V.N. (1987) Population dynamics of male euglossine bees in Amazonian Forest fragments. Biotropica 19, 176-179

Ramalho, A.V., Gaglianone, M.C., Oliveira, M.L. (2009) Comunidades de abelhas Euglossina (Hymenoptera, Apidae) em fragmentos de Mata Atlântica no Sudoeste do Brasil. Rev. Bras. Entomol. 53 (1), 95-101

Ramalho, M., Rosa, J.F., Silva, M.D., Silva, M., Monteiro, D. (2013) Spatial distribution of orchid bees in a rain forest/rubber agro-forest mosaic: habitat use or connectivity. Apidologie 44 (4), 385-403

Rasmussen, C. (2009) Diversity and abundance of orchid bees (Hymenoptera: Apidae, Euglossina) in a tropical rainforest succession. Neotrop. Entomol. 38(1), 066073

Raw, A. (1989) The dispersal of euglossine bees between isolated patches of eastern Brazilian wet forest (Hymenoptera, Apidae). Rev. Bras. Entomol. 33, 103-107

Ricketts, T.H. (2001) The matrix matter: effective isolation in fragmented landscapes. Am. Nat. 158(1), 87-99

Roubik, D.W., Hanson, P.E. (2004) Orchids Bees: Biology and Field Guide. INBIO, San Jose
Roulston, T.H., Goodell, K. (2011) The role of resources and risks in regulating wild bee populations. Annu. Rev. Entomol. 56, 293-312

Sanderson, J., Alger, K., Fonseca, G.A.B..., Galindo-Leal, C., Inchausty, V.H., Morrison, K. (2003) Biodiversity Conservation Corridors: Planning, Implementing, and Monitoring Sustainable Landscapes. Conservation International, Washington

Sofia, S.H., Suzuki, K.M. (2004) Comunidades de machos de abelhas Euglossina (Hymenoptera: Apidae) em fragmentos florestais no sul do Brasil. Neotrop. Entomol. 33 (6), 693-702

Steffan-Dewenter, I. (2003) Importance of habitat area and landscape context for species richness of bees and wasps in fragmented orchard meadows. Conserv. Biol. 17 (4), 1036-1044

Steffan-Dewenter, I., Tscharntke, T. (1999) Effects of habitat isolation on pollinator communities and seed set. Oecologia 121, 432-440

Tischendorf, L., Fahrig, L. (2000) On the usage and measurement of landscape connectivity. Oikos 90, 7-19

Tonhasca, A., Blackmer, J.L., Albuquerque, G.S. (2002) Abundance and diversity of euglossine bees in the fragmented landscape of Brazilian Atlantic Forest. Biotropica 34 (3), 416-422

Tonhasca, A., Albuquerque, G.S., Blackmer, J.L. (2003) Dispersal of Euglossine bees between fragments of the Brazilian Atlantic Forest. J. Trop. Ecol. 19, 99-102

Van Nieuwstadt, M.G.L., Ruano Iraheta, C.E. (1996) Relation between size and foraging range in stingless bees (Apidae, Meliponinae). Apidologie 27, 219-228

Wiens, J.A. (2007) Introduction: Connection research what are the issues? In: Crooks, K.R., Sanjayan, M. (eds.) Connectivity conservation, pp. 23-27. Cambridge University Press, Cambridge

Wikelski, M., Moxley, J., Eaton-Mordas, A., López-Uribe, M.M., Holland, R., Moskowitz, D., Roubik, D.W., Kays, R. (2010) Large-range movements of neotropical orchid bees observed via radio telemetry. PLos One $5(5), \mathrm{e} 10738$

Winfree, R., Bartomeus, I., Cariveau, D.P. (2011) Native pollinators in anthropogenic habitats. Annu. Rev. Ecol. Evol. Syst. 42, 1-22 